Article

\title{
Detecting Looming Vetoes: Getting the European Parliament's Consent in Trade Agreements
}

\author{
Marie Peffenköver ${ }^{1, *}$ and Johan Adriaensen ${ }^{2}$ \\ ${ }^{1}$ Independent Researcher, Belgium; E-Mail: marie.peffenkoever@t-online.de \\ ${ }^{2}$ Faculty of Arts and Social Sciences, Maastricht University, The Netherlands; E-Mail: j.adriaensen@maastrichtuniversity.nl \\ * Corresponding author
}

Submitted: 15 January 2021 | Accepted: 15 June 2021 | Published: 30 July 2021

\begin{abstract}
Since the implementation of the Lisbon Treaty, the European Parliament wields the power of consent over international (trade) agreements, enabling it to threaten a veto. Due to the extensive financial and reputational costs associated with a veto, the European Commission (hereinafter Commission) was expected to read these threats effectively. However, the Commission's responses to such threats have varied greatly. Building on a fine-grained causal mechanism derived from information processing theory and an extensive process-tracing analysis of seven free trade agreements post-Lisbon, we explain why the Commission has responded differently to looming vetoes. Our analysis reveals that the variation in Commission responses derives from imperfections in its information-processing system, the 'early-warning system,' which had to be adapted to the new institutional equilibrium post-Lisbon. Because of this adaption process, factors exogenous to the parliamentary context ('externalities') as well as internal uncertainties ('internalities') add constant unpredictability to the Commission's reading of the European Parliament.
\end{abstract}

\section{Keywords}

EU trade policy; European Commission; European Parliament; information processing theory; trade agreements; veto

\section{Issue}

This article is part of the issue "Resilient Institutions: The Impact of Rule Change on Policy Outputs in European Union Decision-Making Processes" edited by Ariadna Ripoll Servent (University of Salzburg, Austria) and Angela Tacea (Vrije Universiteit Brussel, Belgium).

(C) 2021 by the authors; licensee Cogitatio (Lisbon, Portugal). This article is licensed under a Creative Commons Attribution 4.0 International License (CC BY).

\section{Introduction}

With the power to reject international trade agreements, the European Parliament (hereinafter EP) received a costly 'whip' to sanction the EU negotiator during the final ratification stage. As this 'nuclear option' (Smith, 1999, p. 76) coincided with the politicisation of trade policy, it was widely anticipated that the EP would flex these new 'muscles' frequently. Considering the high financial and reputational costs of looming vetoes, one would expect the European Commission (hereinafter Commission) to read and react to such threats effectively (Gastinger, 2016).

Indeed, there have been several cases where the Commission was uncertain if a majority of Members of the European Parliament (MEPs) would approve the agreement and only realised the impending rejection later or even too late in the process. Such was the case with the Anti-Counterfeiting Trade Agreement (ACTA) where late-stage protests entrapped MEPs to reject the entire agreement. In other cases such as the Comprehensive Economic Trade Agreement (CETA), the Commission reacted to demands backed by a majority of MEPs by re-opening the concluded negotiations. Yet again in other cases such as the agreement with Colombia and Peru (CoPe), the Commission addressed parliamentarians' concerns in a more sufficient manner. Hence, despite the threat of a parliamentary veto having loomed over several cases, the Commission's reaction thereto has varied. We therefore pose the research 
question: Why has the Commission read and reacted differently to threats of vetoes? We deliberately distinguish between a 'veto threat' and the 'threat of a veto': The terminology 'veto threat' suggests an actor-centred concept where A compels B to do something (Cameron, 2000, p. 85). A 'threat of a veto,' on the other hand, suggests a more situational concept where different variables produce a situation where a veto becomes a likely policy option. In this article, we aim to explain why such situational threats have produced varying reactions from the Commission.

As we explain in the second section, the existing literature commonly sees this as a form of brinkmanship, meaning that both institutions are locked in a 'chicken game' with the EP wanting to assert its newly gained powers, and the Commission shifting the burden of rejection to the EP. While such approaches can capture the various outcomes observed, they mischaracterise much of the inter-institutional dynamics surrounding trade negotiations. Our analysis, by contrast, focuses on the communication between the EP and the Commission by applying insights from information processing theory (IPT).

We deliberately focus on the communicative interaction between the Commission and the EP: First, the Council has been the main legislator in trade policy since the establishment of the Common Commercial Policy in 1957. The Commission-Council working relationship is therefore well-established, meaning that we can expect the Commission to be capable of anticipating the sensitivities of the member states. Second, the EP consists of significantly more 'voices' that can transfer signals to the Commission. It thus poses a new challenge in terms of institutional communication. By focussing on the Commission-EP interaction, we thus aim to assess how the rule changes introduced by the Lisbon Treaty increased the chance of rejection of trade agreements as the Commission needed to cope with a new veto player. Yet, considering that the Commission-EP interaction does not take place in a political vacuum, we consider the communicative 'interference' of the Council at key points in our analysis in order to provide a more complete picture of the information exchange between the institutions.

Focusing on processes of organisational learning, we claim that the Commission had to pay some tuition costs as it learned to decipher the signals emitted by the EP. Our deduced mechanism can explain initial vetoes following the entry into force of the Lisbon Treaty such as ACTA but also the disappearance of formal rejections in recent debates. Yet, it is weaker in offering insights into the recurrent bouts of late-stage contestation, even if the issue has ultimately been resolved.

Our empirical analysis comprises of two parts: The first part traces the ratification of three agreements in the 'early post-Lisbon period' (2009-2012). The second part studies three additional trade negotiations in the 'later post-Lisbon period' (2012-2020) when the impli- cations of the treaty change had manifested within the institutions' political awareness (Ripoll Servent, 2014, p. 569). From these findings, we deduce the role of 'internalities' (factors internal to the EU institutional context) and 'externalities' (factors external to the EU institutional context) that necessitate a constant updating of the Commission's information-processing system. Precisely because of this continuous refinement process under constant uncertainty, we argue that reading veto threats resembles efforts to hit 'moving targets,' hence explaining the recurrent stand-offs between EP and Commission late in the negotiations.

\section{Wielding Institutional Power, or a New Parliament in a New Era}

The EP's more prominent role post-Lisbon in EU trade policy informed debates on parliamentary assertion, but also provided a new test case for principal-agent scholars scrutinising inter-institutional dynamics in trade negotiations. The former tradition is particularly useful in shedding light on the EP's motivations and strategies to expand and apply its power. The latter complements such insights by introducing the main target of the EP's actions in trade negotiations. Neither, however, gives due attention to the communicative action through which parliamentary power is asserted.

\subsection{Parliamentary Assertion: Stories of Empowerment}

With the Treaty of Lisbon, the EP received three new rights: the right to be fully informed, the right to accept or reject trade agreements, and the right to implement trade legislation through internal legislation (Art. 207 TFEU, Art. 218 TFEU). These rule changes bundled academia's focus in two ways: On the one hand, an audience-centred focus gave centrality to the growing awareness of the EP's new powers in the eyes of the public. As the argument goes, the increasing public salience of EU affairs following the Lisbon Treaty activates MEPs' desire to 'flex muscles' vis-à-vis the Commission, considering that politicians are subject to election cycles (Gheyle, 2016, p. 2, 2019, p. 20). The politicisation of trade policy hence produced a parliamentary actor which rose 'from zero to hero' (Rosén, 2015) in the eyes of the public and which "[became] active in speaking out with its autonomous voices and expressing autonomous views" (Shaohua, 2015, p. 3).

Other scholars focus on how the rule changes introduced by the Lisbon Treaty have induced the EP to actively leverage its powers beyond formal constitutional rules. Supporters of 'parliamentary assertion' argue that the EP has "come of age" (Roederer-Rynning \& Greenwood, 2016, p. 735) through the Lisbon Treaty, seeking to "institutionalise [its] power in everyday policymaking" (Roederer-Rynning, 2017, p. 2, emphasis in the original). Significant contributions have been published on the SWIFT agreement (Ripoll Servent, 2014), 
the EU-Korea (KOREU) negotiations (Park, 2017), ACTA, and TTIP (Roederer-Rynning, 2017). In a similar vein, defendants of the informal governance approach claim that informal contact nodes outside of formal decisionmaking procedures create space for political actors to bend these formal rules in their pursuit for greater power (Christiansen et al., 2003; Christiansen \& Neuhold, 2012; Stacey, 2012). How the EP has leveraged its powers (with varying success) in the area of external negotiations has been documented extensively (Héritier et al., 2019; Kerremans et al., 2019). From these perspectives, the escalation of threats reflects a strategic act of brinkmanship in which the EP seeks to increase its leverage by taking the entire process hostage.

Yet, such an interpretation omits long-standing insights of negotiation theory, which suggests that 'the early bird' is more likely to 'catch a worm' (Panke, 2010; Thorhallsson \& Wivel, 2006). This would imply that a latestage threat is less a strategic choice and more a measure of last resort after a (perhaps lengthy) negotiation. The dynamic of such inter-institutional negotiations is at the heart of the principal-agent model.

\subsection{Principal-Agent Models: Exploiting Asymmetries, Remaining in Control}

Principal-agent models study an agent's (here the Commission) efforts to engage into opportunistic behaviour ('shirking') while principals (here the EP) seek to remain in control of the agents' actions (Delreux \& Adriaensen, 2017; Delreux \& Kerremans, 2010).

Applied to EU trade policy, most studies focus on the Council and on the conditions under which it can effectively control the Commission (da Conceição-Heldt, 2011; Kerremans, 2004). While these studies are useful in assessing different control mechanisms and the motives for triggering these, they suffer from a "remarkably thin view of agent behaviour" (Hawkins \& Jacoby, 2006, p. 199). Isolating the influence of the EP independently from that of the Council has emerged as another challenge as the same concerns tend to be raised in both institutions. Studies attributing a more central role to the agent can address both critiques by looking directly at the agent's responses to control exerted by a principal (see also Gastinger \& Adriaensen, 2019).

Such "agent-principal approaches" (Delreux \& Adriaensen, 2017, p. 9) have mapped strategies for agents to expand their autonomy by shifting their principals' preferences (Elsig \& Dupont, 2012), limiting monitoring efforts (da Conceição-Heldt, 2017) or shifting the burden of rejection (Delreux \& Kerremans, 2010). Others have looked at the broader context in which the agent operates as a source of autonomy (Planck \& Niemann, 2017). The thematic focus on control and the efforts to escape therefrom are innate to principal-agent models and suggest a view of inter-institutional relations as conflictual. The escalation of a threat is interpreted as a form of (deliberate) shirking, meaning that the agent purposely pursues its own objectives against the preferences of the principal. This assumption is, however, difficult to maintain as it would be unreasonable for the Commission to jeopardise the entire agreement after lengthy negotiations.

Coremans and Kerremans (2017) show how the Commission set up a system of additional meetings and briefings for the Council to ultimately avoid 'involuntary shirking.' They sketch the idea of an agent trying to anticipate what its principals want (Sobol, 2016). This compels us to give more attention to the communication between both institutions. Studies using such an approach have revealed a far more nuanced picture of inter-institutional relations. For example, Coremans (2020) showed how the increasing access to information by the EP exposed capacity constraints and ultimately led to the embrace of informal governance arrangements as a coping mechanism. Moving our focus towards the Commission, we aim to explain its (lack of) responsiveness to threats of vetoes.

\section{An Information-Processing Perspective on Institutional Interaction}

The communicative aspect of institutional interaction is particularly relevant considering the huge amount of information that the EU institutions exchange regularly'information overload' as the political scientist Herbert Simon put it most famously in 1971. As human beings are constantly flooded with information, Simon (1971) argued that "information consumes the attention of its recipients" (p. 6). The ability of individuals to distinguish between relevant and irrelevant information is thus central to the functioning of all organisational processes. This law of attention scarcity laid the foundations for IPT.

Institutions hence need to clear the 'noise' that surrounds them on a daily basis, given that they cannot pay equal attention to all signals simultaneously. Applied to our case, the Commission is flooded by information from the EP and needs to figure out upon which demands it has to act. In other words, once information, which we define as a preference on substantive issues, has been released, IPT assumes the recipient to undertake an assessment or prioritisation of whether this piece of information is 'worthy' of attention (Walgrave \& Dejaeghere, 2017, pp. 235-237).

Political psychologists later extended this notion by arguing that attention is scarce because human beings cannot process several pieces of information simultaneously. The law of serial processing implies that recipients, once they have made an initial prioritisation, need to rely on heuristics, so-called 'signals,' in order to interpret the information received (Axelrod, 1973; Feldman \& March, 1981). IPT hence assumes signal interpretation to be a corollary of prioritisation of information (Jones \& Baumgartner, 2005). Naturally, this latter step leaves room for misinterpretation, given that information can be both uncertain (i.e., the precise value of the estimate 
is not set) and ambiguous (i.e., it is subject to more than one interpretation; Jones \& Baumgartner, 2012, p. 7). Misreading information may lead to inefficient policy decisions and hence to a sanction. We interpret the meaning of 'sanction' broadly: It is not just the rejection of an agreement, but also the reputational 'shaming' when the Commission is pressed to re-open negotiations it considered concluded. Importantly, IPT assumes that consequences of both correct and incorrect information processing produce positive and negative feedback loops, meaning that human beings learn from their past experiences (Jones \& Baumgartner, 2012, p. 3; Workman et al., 2009, p. 81). This is called the law of learning.

These three laws provide fitting premises for our research question as institutions constitute of, produce, and exchange information. In applying them, we seek to add novel and relevant insights to the literature on inter-institutional relations by understanding interinstitutional conflict as positive and negative feedback loops of information processing at work.

Figure 1 projects the three laws of IPT to the context of Commission-EP interaction in EU trade policy. The Commission receives signals from the EP on a daily basis (information reception; $x$ ). The challenge for the Commission is then to first assess the urgency of that demand for which, as we will introduce later, it relies on its own information-processing system, the 'early-warning system' (EWS). As the law of serial processing highlights, signal interpretation leaves room for misreading. Therefore, two pathways emerge: (1) The Commission might correctly anticipate the urgency of the demand, meaning that it anticipates the demand's potential to escalate. The result is institutional pacification which renders the ratification of a trade agreement more likely (pacification route); and (2) The Commission might misread the demand's potential to escalate (escalation route). In this case, we expect a sanction to be more likely. Such a sanction takes the form of an expected loss of authority or discretion in future negotiations. Hence, it is not just the rejection of an agreement, but also the reputational 'shaming' of the Commission in case it needs to re-do its work (e.g., when re-opening negotiations).

In accordance with the law of learning, both institutional escalation and institutional pacification trigger organisational learning. This means that we understand organisational learning as an integral part of institutional communication which is generated by both positive and negative feedback loops. These feedback loops are summarised on p. 8 of our online Supplementary File; a full operationalisation of every causal step can be found on pp. 6-7 of our online Supplementary File. If we follow the logic of IPT, information processing should improve over time, leading to fewer occasions of sanctioning. Contrary to the literature on parliamentary assertion or on principal-agent models, our information-processing perspective hence suggests that the escalation of threats of vetoes is better understood as an error in communication rather than a strategic act of brinkmanship.

\section{Research Design}

To scrutinise communicative interaction, qualitative expert interviews constituted our main data collection

Pacification of inter-institutional relations

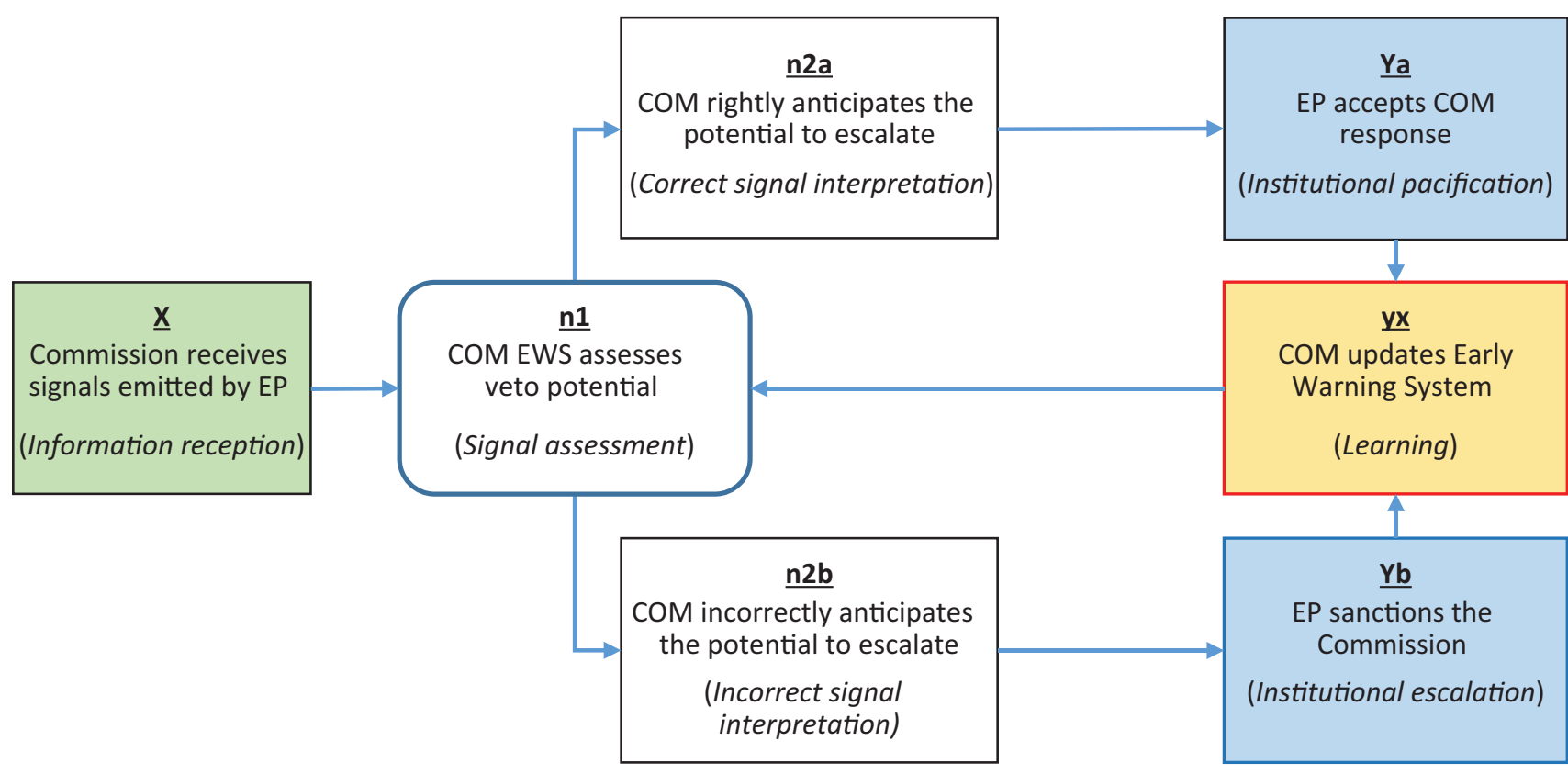

Escalation of inter-institutional relations

Figure 1. Learning to read veto threats-A causal mechanism. 
method (Rubin \& Rubin, 2012). In total, we carried out 12 semi-structured expert interviews with high-ranking Commission officials from DG Trade and with MEPs (or their assistants) from the Committee on International Trade (hereinafter INTA). We strategically recruited our Commission interviewees from the (deputy) head of unit and director level because these high-ranking officials sit at the heart of processing information about potential vetoes (Hooghe \& Rauh, 2017, pp. 195-196; Nugent \& Rhinard, 2015, pp. 174-175).

Additionally, we interviewed trade experts from INTA, the key contact point for DG Trade during trade negotiations. 'Trade experts' are MEPs which are well versed in trade politics and are therefore seen by their colleagues to be experts in this field. This includes for example group coordinators in INTA but also former (shadow) rapporteurs of trade policy dossiers or MEPs who monitored trade policy before joining the EP.

The interviews were carried out in two rounds (April-June 2019 and February-March 2020) and included a ranking exercise (see pp. 3-4 of our online Supplementary File) which asked interviewees from both the Commission and the EP to rank ten parliamentary signals. The results of the ranking exercise can be found in our online Supplementary File. Additionally, we collected four types of policy documents-parliamentary questions, resolutions, follow-up fiches to resolutions, and Civil Society Dialogues-to triangulate our interview data.

Our analysis includes both cases of institutional pacification and cases of institutional escalation. If we would only study the latter, we would fail to capture the results from the Commission's learning processes. As cases of institutional pacification, we identified KOREU (2011), CoPe (2012), the Singapore agreement (EUSFTA, 2019) and the Vietnam agreement (EVFTA, 2020). Cases of institutional escalation are ACTA (2012), TTIP (not concluded), CETA (2017) and the Uzbekistan agreement (2016). This selection emerged directly from initial interviews conducted with our Commission officials.

To analyse our data, we apply theory-testing process tracing (Beach \& Pedersen, 2013, p. 20). This variant of process tracing provides us with a systematic method to first reconstruct the process of receiving and processing information in theory and then to gauge the reading of a threat of veto 'in action.' This method is hence particularly apt to answer our research question because it allows us to dive deep into our individual-level data.

In the following part, we apply this research design to show that: (1) The Commission's initial EWS comprised a small network of key players within DG Trade and in INTA and had to be updated; and (2) While this recalibrated system later provided the Commission with broader monitoring capacities, external shocks could still escape the system. As a result, the rule changes introduced by the Lisbon Treaty led to more latent powers of the EP in EU trade policy by aggravating the permeability of external shocks and uncertainties in the com- municative interaction of the EU negotiator and an EU co-legislator.

\section{Empirical Analysis}

\subsection{The Early Post-Lisbon Period (2009-2012): "We Are Institutional Partners"}

Already prior to the implementation of the Lisbon Treaty, the Commission anticipated that the rule changes introduced by the Lisbon Treaty would result in a new institutional equilibrium. Seeking to mitigate this 'structural shock,' the Commission constructed what one of our interviewees called an "early-warning system" (EWS; Interview 11). The term EWS should not be confused with the procedure established by the Lisbon Treaty to coordinate national parliaments' subsidiarity checks. In our case, the EWS initially referred to institutional contact nodes, i.e., personal networks with 'lifelines' (such as regular meetings or an exchange of documents) between the staff of DG Trade's inter-institutional unit and key players in INTA, mostly the group coordinators and the committee chair (Interviews 5, 8, 9, 11). The initial EWS hence provided the attempt of an "institutional safety net" (Interview 4) that aimed to uphold constant communicative interaction with the 'new' institutional partner.

The resilience of this safety net was quickly put to the test by KOREU and CoPe, whose negotiations were finalised not even a year after the entry into force of the Lisbon Treaty (Interview 2). Although issues of exporter discrimination (KOREU) and human rights abuses (CoPe) triggered concern within civil society and some parts of the EP already during the pre-negotiation phase, the Commission negotiators trusted in the lifelines established by their initial EWS (Interview 12).

In the case of KOREU, it was the Council's Trade Policy Committee which turned into the epicentre of a large-scale lobbying campaign by the European automobile industry. Arguing that duty drawback would allow Korean car manufacturers to buy car components in China and to claim back duties when the final cars would be exported to the EU, the car industry sought to eliminate the provision (Ahn, 2010, p. 12; Elsig \& Dupont, 2012, p. 500; Interview 12). This lobbying pressure spilled over to the EP over the first half of 2010: On 23 June 2010, INTA adopted no less than 54 amendments during its first legislative reading on its owninitiative report, most of which were formulated with a strong language (Kleimann, 2011, p. 23; see p. 9 of our online Supplementary File). Additionally, strong voices came from Bernd Lange (S\&D, Germany) and Michael Theurer (ALDE, Germany), two prominent INTA members. As more and more MEPs became open to the argument of exporter discrimination through duty drawback, the majority ratios in the EP began to shrink (Interviews 1, $2,12)$. These developments signalled to the Commission that the issue of duty drawback contained high threat 
potential and explains why interaction with INTA was placed as the second most important parliamentary signal in our ranking exercise (step $n 1$ ).

Similarly, CoPe became subject to early lobbying. Human rights NGOs approached MEPs from the GUE/NGL and the Greens for whom human rights concerns are traditionally salient (Interview 2; Dijkstra, 2017, p. 23). Following mass assassinations of trade unionists in Colombia in 2008 and 2009, also larger parts of the S\&D began to criticise the agreement, thus potentially threatening ratification (step $n 1$; see p. 9 of our online Supplementary File).

Given that the Parliament had merely published "a very supportive resolution [on KOREU] that had been adopted by the European Parliament with the support of practically all political groups" (Interview 1 ) and none on $\mathrm{CoPe}$, the Commission negotiators were taken by surprise as an element external to its institutional contact nodes threatened the fragmentation of the plenary (Interviews 1, 8, 11).

The Commission nevertheless attributed these issues a low potential to escalate: In case of KOREU, the EP had merely published one supportive resolution and had otherwise been rather uninterested in the negotiations (see p. 6 of our online Supplementary File). In case of $\mathrm{CoPe}$, contacts with parliamentary key players offered the impression that the more neo-liberal parties (EPP, ALDE, ECR) were not willing to reject a trade-beneficial agreement because of human rights issues (step $n 2 a$; p. 10 of our online Supplementary File).

Having interpreted these signals, the Commission sought to pacify a potential rejection by appealing to the EP's responsibility as an institutional partner and by formalising concessions through public statements, thus raising the cost of rejection (Interviews 1, 4, 7, 11, 12). In subsequent meetings with INTA key players, Commission officials stressed the mutual interest to ratify the agreements and reminded them that, in case of a rejection, "everybody has to take the responsibilities" (Interview 9). On CoPe, the Commission also negotiated stronger civil society mechanisms (see pp. 12-13 of our online Supplementary File). In the end, the Commission could prevent institutional escalation; both agreements were ratified by a majority of MEPs in 2011 (nya).

In contrast, ACTA and the textile protocol with Uzbekistan which complemented the EU-Uzbekistan Partnership and Cooperation Agreement of 1999 (Interview 8; Yunusov, 2014, p. 5) present cases where looming vetoes escalated. In the case of ACTA, late-stage public dissatisfaction in the member states followed similar initiatives against the Stop Online Piracy Act and the Protect IP Act in the US (Interviews 10, 11; Dür \& Mateo, 2014, p. 1202). While the Uzbekistan protocol was less politicised, child labour in the cotton industry caused public criticism (see pp. 17-18 of our online Supplementary File).

These criticisms took the Commission by surprise, considering that both agreements "[were not] doing any- thing radical" (Interview 10) and that previous resolutions on ACTA had been supportive of the negotiations (p. 14 of our online Supplementary File). Moreover, while the street protests on ACTA placed the EP under close public scrutiny, the main political groups in the plenary (the EPP, the ALDE and the S\&D) as well as majorities in the committees for opinion still supported the agreement until April 2012 (step n1; Interview 8).

This changed in February 2012 when the German social democratic delegation started to oppose the agreement (Interview 10). As civil society actors continued to raise the political heat, MEPs that still supported ACTA became entrapped by this public scrutiny, meaning that it became difficult for them to still vote in favour (Interview 3). After the liberals joined the anti-ACTA camp in April 2012, parliamentary rejection was inevitable (step $n 2 b$ ). On 4 July 2012, a majority of MEPs rejected ACTA (sanction).

In the case of Uzbekistan, human rights issues encapsulated the social democrats (Interview 8). Due to the salience of this issue for social democratic voters, large parts of the S\&D threw their weight behind the critical voices, thus negatively impacting the group cohesion of the S\&D (step $n 2 b$ ). Because the EP was now split almost evenly into supporters and opponents, the ratification of the protocol was delayed by five years - a reaction which comes "pretty close to voting down" (sanction; Interview 9).

Considering the Commission's previous success in pacifying looming vetoes, ACTA and Uzbekistan seem surprising. However, while the EWS had provided samples of the political atmosphere in the committees, it had not captured information on the strategic sensitivities of MEPs caused by external dynamics. As both ACTA and Uzbekistan addressed only a limited range of stakeholders, did not lower the EU's regulatory standards, and were already rejected by the public, the costs of rejection were manageable (Interviews 10,11). Despite MEPs having communicated support, the 'shock waves' of public protest rendered rejection a rational choice (Interview 5). The EWS had hence communicated a wrong picture of the political atmosphere in the committees and had led to misreading the situations.

\subsection{The Later Post-Lisbon Period (2012-2020): Learning from Disaster?}

From these experiences, it became clear that the initial EWS required recalibration (Interview 12 ). While personal contact nodes which had been deliberately established pre-Lisbon had certainly proven useful, KOREU, CoPe and ACTA had shown that broader monitoring of societal movements, public pressure and lobbying was necessary. The initial EWS was therefore revised by being broadened in scope and in depth: To deepen the institutional contact nodes, DG Trade allocated more resources to its inter-institutional unit (Interviews 7, 10). Additionally, more regular channels of communication 
such as monitoring groups were introduced to improve DG Trade's reading of the Parliament (Interviews 7, 9, 10). To broaden the scope of the EWS, DG Trade's communications unit received more financial and staff resources to better communicate with national and regional journalists, NGOs, and civil society actors (Interview 11). As one interviewee stressed, "since then, my sense is that we would really have to be a little bit blind if we [would] not identify that [something] is problematic" (Interview 1).

However, after ACTA, the EP showed a particular 'appetite' for confronting its institutional counterparts (Roederer-Rynning, 2017, p. 9). It deliberately adopted its first TTIP resolution on 23 May 2013, one day before the Council officially published the negotiation directives. In a section explicitly labelled 'mandate,' the resolution underlined with the wording of a "clear-cut exclusion" (Interview 9) that the negotiations should exclude audiovisual services. The section "the role of the Parliament" "recall[ed] that Parliament will be asked to give its consent to the future TTIP agreement" (EP, 2013a, Art. 25).

At the same time, criticism on investor-to-state dispute settlement (ISDS) began to grow within civil society. Following a number of high-profile ISDS cases such as the triumph of the Swedish energy company Vattenfall over the German government (Siles-Brügge, 2018, p. 14), the German EPP and S\&D delegations came under pressure (De Bièvre, 2018, p. 73). Although the grand coalition of S\&D and EPP in the plenary still stood firm (Roederer-Rynning, 2017, p. 520), TTIP was beginning to show the same characteristics as ACTA (step n1; see p. 19 of our online Supplementary File).

Therefore, the Commission stalled the negotiations while launching a public consultation (step $n 2 a$; Interviews 10, 12). However, because its relationship with INTA was working "at the highest level" (Interview 7), the Commission was "wrongly confident" (Hübner et al., 2017, p. 852) that CETA, which was being negotiated in parallel to TTIP, would be ratified (step $n 1$; Interviews 8,11 ). While TTIP was stalled, the Commission therefore continued the negotiations on CETA (Interview 11). Trusting in the EP's long-term support for the agreement, the Commission misread the degree of politicisation and the contentiousness of ISDS in the EP (step $n 2 b$ ). After CETA's official conclusion on 26 September 2014, the political left directly threatened to veto (Interview 2). When on 4 March 2015, the S\&D cast a vote on its official group line, an overwhelming majority voted to oppose ISDS in TTIP and CETA (Siles-Brügge, 2018, p. 18). Due to these fault lines, the plenary vote on CETA which was originally scheduled for 10 June 2015 had to be postponed (sanction; Roederer-Rynning, 2017, p. 521).

During the drafting process of the EP's second TTIP resolution, most amendments which explicitly "oppose[d] the inclusion of an ISDS mechanism in TTIP" (Amendment 106) were tabled by the Left and the Greens (also Amendments 27, 72, 108), some also by the S\&D (e.g., Amendment 115). The final resolution of 8 July 2015 therefore demanded to "replace the ISDS system with a new system for resolving disputes between investors and states" (EP, 2015, Art. xv). In particular the social democrats made their opposition to TTIP very explicit: On 10 November 2015, Sorin Moisă (S\&D, Romania) directly addressed the Commission during a plenary debate, stating that "ISDS is the thorn in the flesh of CETA" (Hübner et al., 2017, p. 853). Although being ranked as the least important signal, the plenary speech renders the looming rejection more credible as it becomes more difficult for MEPs to back down (Interview 11). It had hence become clear that "having ISDS in CETA, CETA would not be... accepted" (Interview 5; steps $n 1, n 2 a$ ).

To avoid a second ACTA, Trade Commissioner Cecilia Malmström and the President's cabinet decided in November 2015 to "make the treaty more acceptable" by re-negotiating the investment chapters of TTIP and CETA (step n2a; see p. 23 of our online Supplementary File; Interviews 4, 5). Accordingly, the Commission replaced ISDS with an Investment Court System which mirrored, with some adjustments, the WTO Appellate Body (Alvarez, 2020, pp. 10-11). On 15 February 2017, the agreement was narrowly accepted with $54.3 \%$ (step nya). TTIP and CETA hence taught the Commission how to find flexible and creative solutions in order to address looming vetoes during the 'end-game.'

More recent trade agreements such as the ones with Singapore (2019) or Vietnam (2020) support this flexible learning process. As the final negotiation rounds of both agreements overlapped with CETA's 'hot phase,' they faced similar public and parliamentary criticism (step $n 1$; Hindelang et al., 2019, pp. 17-18; McKenzie \& Meissner, 2017 , p. 6). However, as public attention was predominantly focused on TTIP and CETA, Singapore and Vietnam were never explicitly politicised (step $n 2 a ;$ p. 25, 27 of our online Supplementary File).

Nevertheless, the Commission stalled the negotiations on Singapore while re-negotiating TTIP and CETA (Interview 4) and constantly interacted with key players in INTA. In 2017, following a European Court of Justice opinion, it decided "to take the [Singapore] agreement and... split it in two: [One] part of the agreement [being] EU-only which is $99 \%$ of the agreement and a small part of the agreement covering investment" (Interview 11).

This decision had also been taken in light of the upcoming ratification of the EU-Vietnam agreement. Due to Vietnam's history of human rights abuses, DG Trade anticipated a dynamic similar to the CoPe negotiations (Interview 1). The potential explosiveness of human rights concerns revealed itself over the course of the EP's resolution on Vietnam of 18 April 2013 within which the EP emphasised the importance of human rights stipulations (EP, 2013b, Art. 11). When the Vietnamese government stressed that the inclusion of human rights stipulations was a dealbreaker (Thu \& Schweisshelm, 2020, p. 19), it was clear that the situation could potentially turn into a veto (step $n 1$ ). Yet, as 
Vietnam was never explicitly politicised, the Commission read the Vietnam case similar to CoPe: Although human rights issues had turned into a salient topic, the lack of politicisation indicated that there were fewer incentives for parliamentarians to strategically vote against the agreement (step $n 2 a$ ). To still address the issue, the Commission negotiators proposed to strengthen "the possibility of suspension of the PTA in case of severe human rights abuses" (Sicurelli, 2015, p. 240) and supported an INTA mission to Vietnam (Interview 8). In their resolution of 9 June 2016, MEPs 'applauded' this compromise (EP, 2016, Art. 1). The agreement received a two-thirds majority on 13 February 2020 (step ya; see p. 28 of our online Supplementary File).

\subsection{External Shocks, Internal Uncertainties}

Our analysis thus confirms that both positive and negative information-processing experiences have necessitated a constant adjustment of the Commission's EWS. However, we also highlighted throughout that, no matter how close the working relationship between both institutions, different types of uncertainties can impede the proper reading of signals emitted by the EP.

Hence, organic externalities add unpredictability to the institutional context. While past politicisation of a specific issue will trigger adaptation of the EWS, "[sic] there's always a risk" (Interview 7) when reading the EP. Indeed, ISDS had been used in investment agreements for over half a century without causing controversy. Lobbying efforts (KOREU, CoPe, ACTA, Uzbekistan, CETA, Vietnam), mass mobilisation (ACTA, TTIP/CETA) and entrapment by public scrutiny (ACTA, CETA, Vietnam) can thus create unpredictable impediments in the ratification process.

Yet, our analysis also revealed that this unpredictability stems from within the EP itself. While resolutions were unanimously ranked as the most important parliamentary instrument in our ranking exercise, our analysis showed that these are typically supportive. This produces a communicative mismatch between information and content. The internal cohesion of the parliamentary groups, most notably the $S \& D$, is another internal factor of uncertainty: Not only does the S\&D consist of highly heterogenous national delegations (Interviews 2, 8 ), but also tends to "make up its mind... only the night before the [final] vote" (Interview 8). This late-stage voicing of criticism renders it difficult for the Commission to respond to potential obstacles in time.

Together, externalities and internalities create 'white noise' which impedes the Commission's proper reading of signals emitted by the EP. When analysing interinstitutional communication, it is pertinent to consider this scope condition: As we have shown, processing information does not take place in a 'clean' institutional environment but is subject to and hindered by obstacles that lie both within and outside of this institutional scope. While IPT suggests that one should see fewer institu- tional escalations over time, we argue that 'failure' is still possible as internal and external uncertainties produce a constant residual risk of misreading information. Our argument thus highlights the informational challenges that can undermine policy coordination. Against this background, we argue that from an informationprocessing perspective, policy output refers to the lack of 'visible' output, i.e., no agreement has been ratified. The addition of this 'white noise' as a scope condition to IPT is one of the main contributions of our article.

This residual risk is furthermore aggravated by the human nature of the EWS: As the EWS relies on interpersonal contacts and individuals' experience, changes in the personal set-up of this network impact the systems' institutional memory. Considering that the EP changes each election cycle, and considering that Commission officials regularly move positions, past lessons may be forgotten or may become outdated. It is thus not only the Damocles' Sword of 'white noise' that is looming over inter-institutional information processing. In fact, learning itself is a dynamic process which needs to perpetuate to cope with the continuous change in political landscape. Hence, the veto potential of different substantive concerns needs to be re-assessed continuously.

\section{Conclusion}

While the Lisbon Treaty has been in force for more than a decade, the relationship between the EP and the Commission remains in flux. High profile confrontations have resulted in the delay or even rejection of trade agreements. The existing literature commonly explains these as a strife for parliamentary empowerment or as a game of brinkmanship gone awry. Yet, both explanations sit at odds with the rather constructive and respectful manner in which both institutions have worked on many of the concerned trade agreements.

To understand this outcome, we advocate the use of an information-processing perspective which suggests that the escalation of threats is better understood as a communicative error. As the newly gained powers of the EP did not come with an instruction manual, the Commission required time to gain experience in reading this highly diverse and decentralised partner that is sensitive to shifts in the public agenda. Central in this process has been the elaboration of an information-processing system, the 'early-warning system,' with which the Commission seeks to identify possible vetoes amidst the many signals emitted by the EP and its members.

This system, as we have shown, is continuously adapted as institutions learn from prior experiences. While this seems to suggest that the Commission develops nearly perfect information-processing capacities over time, we have shown that externalities like a sudden mobilisation of public opinion and the unpredictable responses from MEPs thereupon can still catch the Commission off guard. 'White noise' is therefore an 
important scope condition which indicates that, no matter how fine-grained an information-processing system might be, threats of vetoes still have the potential to escalate. As a corollary, future vetoes are possible if they follow intense political mobilisation during the ratification stage, and if they cover issues that have not been subject to intense parliamentary scrutiny. If the latter condition is not fulfilled, we can assume that the Commission has been able to anticipate the issue.

Beyond an insight on the conditions by which vetoes can be triggered, our article aims to contribute to a broader discussion on inter-institutional relations. By treating threats of vetoes as errors in communication, we escape the simplified depiction of such relations as conflictual or antagonistic. Instead, we gain a more human and practical insight into the messy and often frustrating process by which large collective entities engage in decision-making.

\section{Acknowledgments}

The authors gratefully acknowledge the comments received from Angela Tacea, Ariadna Ripoll-Servent, and from those who provided feedback at the ECPR Joint Sessions in December 2020 and May 2021. Financial support from Maastricht University is acknowledged.

\section{Conflict of Interests}

The authors declare no conflict of interests.

\section{Supplementary Material}

Supplementary material for this article is available online in the format provided by the author (unedited).

\section{References}

Ahn, D. (2010). Legal and institutional issues of Korea-EU FTA: New model for post-NAFTA FTAs? (Policy Brief). ECIPE. https://ecipe.org/wp-content/uploads/2014/ 12/AHN_LEGALANDINSTUTITIONALKOREU_FTA_ 201010.pdf

Alvarez, J. M. (2020). How innovative is the EU's proposal for an investment court system: A comparison between ICS and traditional investor-state dispute settlement (European Union Law Working Paper No. 43). Stanford University. https://law.stanford. edu/publications/no-43-how-innovative-is-theeus-proposal-for-an-investment-court-system-acomparison-between-ics-and-traditional-investorstate-dispute-settlement

Axelrod, R. (1973). Schema theory: An information processing model of perception and cognition. The American Political Science Review, 67(4), 1248-1266.

Beach, D., \& Pedersen, R. B. (2013). Process tracing methods-Foundations and guidelines. University of Michigan Press.
Cameron, C. M. (2000). Veto bargaining. Presidents and the politics of negative power. Cambridge University Press.

Christiansen, T., Føllesdal, D., \& Piattoni, S. (2003). Informal governance in the European Union. Edward Elgar.

Christiansen, T., \& Neuhold, C. (2012). International handbook on informal governance. Edward Elgar.

Coremans, E. (2020). Opening up by closing off: How increased transparency triggers informalisation in EU decision-making. Journal of European Public Policy, 27(4), 590-611.

Coremans, E., \& Kerremans, B. (2017). Agents as information asymmetry managers in EU trade policy-making. In T. Delreux \& J. Adriaensen (Eds.), The principal agent model and the European Union (pp. 227-253). Palgrave Macmillan.

da Conceição-Heldt, E. (2011). Variation in EU member states' preferences and the Commission's discretion in the Doha Round. Journal of European Public Policy, 18(3), 403-419.

da Conceição-Heldt, E. (2017). Multiple principals' preferences, types of control mechanisms, and agent's discretion in trade negotiations. In T. Delreux \& J. Adriaensen (Eds.), The principal-agent model and the European Union (pp. 203-226). Palgrave MacMillan.

De Bièvre, D. (2018). The paradox of weakness in European trade policy: Contestation and resilience in CETA and TTIP negotiations. The International Spectator, 53(3), 70-85.

Delreux, T., \& Adriaensen, J. (2017). The principal agent model and the European Union. Palgrave Macmillan.

Delreux, T., \& Kerremans, B. (2010). How agents weaken their principals' incentives to control: The case of EU negotiators and EU member states in multilateral negotiations. European Integration, 32(4), 357-374.

Dijkstra, J. M. (2017). Normative or market power Europe? The promotion of labour standards in bilateral trade agreements of the European Union with South-Korea, Colombia/Peru and Vietnam [Doctoral Dissertation, Leiden University]. Leiden University Student Repository. https://studenttheses. universiteitleiden. $\mathrm{nl} / \mathrm{handle} / 1887 / 58620$

Dür, A., \& Mateo, G. (2014). Public opinion and interest group influence: How citizen groups derailed the Anti-Counterfeiting Trade Agreement. Journal of European Public Policy, 21(8), 1199-1217.

Elsig, M., \& Dupont, C. (2012). European Union meets South Korea: Bureaucratic interests, exporter discrimination and the negotiations of trade agreements. Journal of Common Market Studies, 50(3), 492-507.

European Parliament. (2013a). EU trade and investment negotiations with the United States of America (Legislative Resolution, P7_TA(2013)0227).

European Parliament. (2013b). Vietnam, in particular freedom of expression (Legislative Resolution, T7-0189/2013). 
European Parliament. (2015). Negotiations for the Transatlantic Trade and Investment Partnership (TTIP) (Legislative Resolution, P8_TA(2015)0252).

European Parliament. (2016). Vietnam (Legislative Resolution, T8-0276/2016).

Feldman, M. S., \& March, J. G. (1981). Information in organizations as signal and symbol. Administrative Science Quarterly, 26(2), 171-186.

Gastinger, M. (2016). The tables have turned on the European Commission: The changing nature of the pre-negotiation phase in EU bilateral trade agreements. Journal of European Public Policy, 23(9), 1367-1385.

Gastinger, M., \& Adriaensen, J. (2019). Of principal(s') interest? A disaggregated, multiple principals' approach to Commission discretion. Journal of Common Market Studies, 57(2), 353-370.

Gheyle, N. (2016, July 6-7). Adding fuel to the flames. How TTIP reinvigorated the politicization of trade [Conference Paper]. Governance and Integration through Free Trade Agreements Conference, Brussels, Belgium. https://biblio.ugent.be/publication/ 8024509

Gheyle, N. (2019). Trade policy with the lights on. The origins, dynamics, and consequences of the politicization of TTIP [Doctoral Dissertation, Ghent University]. Academic Bibliography, Ghent University. https:// biblio.ugent.be/publication/8600487

Hawkins, D., \& Jacoby, W. (2006). How agents matter. In D. Hawkins, D. Lake, D., Nielson \& M. Tierney (Eds.), Delegation and agency in international organizations (pp. 199-228). Cambridge University Press.

Héritier, A., Meissner, K., Moury, C., \& Schoeller, M. (2019). The European Parliament ascendant. Parliamentary strategies of self-empowerment in the EU. Palgrave Macmillan.

Hindelang, S., Baur, J., \& Schill, S. (2019). EU investment protection after the ECJ opinion on Singapore: Questions of competence and coherence (workshop report). European Parliament Research Service. https://www.europarl.europa.eu/thinktank/en/ document.html?reference=EXPO_STU(2019)603476

Hooghe, L., \& Rauh, C. (2017). The Commission services: A powerful permanent bureaucracy. In D. Hodson \& J. Peterson (Eds.), The institutions of the European Union (4th ed., pp. 187-212). Oxford University Press.

Hübner, K., Deman, A. S., \& Balik, T. (2017). EU and trade policymaking: The contentious case of CETA. Journal of European Integration, 39(7), 843-857.

Jones, B. D., \& Baumgartner, F. R. (2005). The politics of attention: how government prioritizes problems. University of Chicago Press.

Jones, B. D., \& Baumgartner, F. R. (2012). From there to here: Punctuated equilibrium to the general punctuation thesis to a theory of government information processing. The Policy Studies Journal, 40(1), 1-19.

Kerremans, B. (2004). What went wrong in Cancun? A principal-agent view on the EU's rationale towards the Doha Development Round. European Foreign Affairs Review, 9(3), 363-393.

Kerremans, B., Adriaensen, J., Coremans, E., \& Colli, F. (2019). Parliamentary scrutiny of trade policies across the Western world. International Trade Committee, European Parliament. http://dx.doi.org/ $10.2861 / 145838$

Kleimann, D. (2011). Taking Stock: EU common commercial policy in the Lisbon era (Working Paper no. 345). CEPS. https://www.ceps.eu/cepspublications/taking-stock-eu-common-commercialpolicy-lisbon-era

McKenzie, L., \& Meissner, K. L. (2017). Human rights conditionality in European Union trade negotiations: The case of the EU-Singapore FTA. Journal of Common Market Studies, 55(4), 832-849.

Nugent, N., \& Rhinard, M. (2015). The European Commission (2nd ed.). Palgrave Macmillan.

Panke, D. (2010). Good instructions in no time? Domestic coordination of EU policies in 19 small states. West European Politics, 33(4), 770-790.

Park, S. (2017). The new politics of trade negotiations: The case of the EU-Korea FTA. Journal of European Integration, 39(7), 827-841.

Planck, F., \& Niemann, A. (2017). Impact of the agent's environment on discretion in the field of EU conflict resolution. In T. Delreux \& J. Adriaensen (Eds.), The principal-agent model and the European Union (pp. 131-155). Palgrave MacMillan.

Ripoll Servent, A. (2014). The role of the European Parliament in international negotiations after Lisbon. Journal of European Public Policy, 21(4), 568-586.

Roederer-Rynning, C. (2017). Parliamentary assertion and deep integration: The European parliament in the CETA and TTIP negotiations. Cambridge Review of International Affairs, 30(5/6), 507-526.

Roederer-Rynning, C., \& Greenwood, J. (2016). The European Parliament as a developing legislature: Coming of age in trilogues? Journal of European public policy, 24(5), 735-754.

Rosén, G. (2015). From zero to hero: Explaining the European Parliament's influence on EU external trade policy (Postdoctoral Research Project). Norwegian Research Council. https://www.sv.uio.no/ arena/english/people/aca/guriros/index.html

Rubin, H. J., \& Rubin, I. S. (2012). Qualitative interviewing: The art of hearing data (3rd ed.). SAGE.

Shaohua, Y. (2015). The European Parliament's role in EU trade policy after Lisbon: Analysis from an actorness approach (Online Paper on Parliamentary Democracy 3/2015). PADEMIA.

Sicurelli, D. (2015). The EU as a promoter of human rights in bilateral trade agreements: The case of the negotiations with Vietnam. Journal of Contemporary European Research, 11(2), 230-245.

Siles-Brügge, G. (2018). Transatlantic investor protection as a threat to democracy: The potency and limits 
of an emotive frame. Cambridge Review of International Affairs, 30(5/6), 464-488.

Simon, H. A. (1971). Designing organizations for an information-rich world. In M. Greensberger (Ed.), Computers, communication and the public interest (pp. 38-72). The John Hopkins University Press.

Smith, J. (1999). The European Parliament: A subordinate institution? In J. Smith (Ed.), Europe's elected Parliament (pp. 63-80). Sheffield Academic Press.

Sobol, M. (2016). Principal-agent analysis and pathological delegation: The (almost) untold story. Governance, 29(3), 335-250.

Stacey, J. (2012). Informal governance in the EU: The European Commission versus the European Parliament. In T. Christiansen \& C. Neuhold (Eds.), International handbook on informal governance (pp. 395-411). Edward Elgar.

Thorhallsson, B., \& Wivel, A. (2006). Small states in the
European Union: What do we know and what would we like to know? Cambridge Review of International Affairs, 19(4), 651-668.

Thu, M. H., \& Schweisshelm, E. (2020). Labour rights and civil society empowerment in the EU-Vietnam Free Trade Agreement (Working Paper No. 135/2020). Institute for International Political Economy Berlin. https://www.econstor.eu/bitstream/10419/ 214649/1/1691499277.pdf

Walgrave, S., \& Dejaeghere, Y. (2017). Surviving information overload: How elite politicians select information. Governance, 30(2), 229-244.

Workman, S., Jones, B. D., \& Jochim, A. E. (2009). Information processing and policy dynamics. The Policy Studies Journal, 37(1), 75-92.

Yunusov, K. (2014). Partnership and cooperation agreements of the European Union with Central Asian countries. Studii Europene, 1, 9-18.

\section{About the Authors}

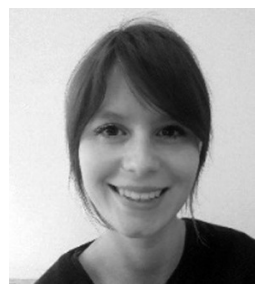

Marie Peffenköver is an Independent Researcher currently based in Brussels, Belgium. Her main research focus is on the institutional level of EU politics with a particular focus on the European Parliament. Since 2017, she has gained hands-on experience in EU politics by working for a Member of the European Parliament on EU trade policy. Marie is a graduate of the Research Master European Studies at Maastricht University.

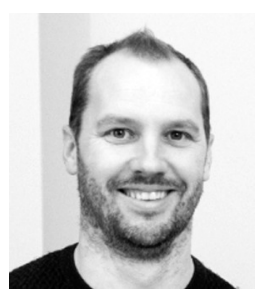

Johan Adriaensen is Assistant Professor at Maastricht University, The Netherlands. His research focuses on institutional politics and EU trade policy. He is the author of National Administrations in EU Trade Policy (Palgrave, 2016). 